Bull. Chem. Soc. Ethiop. 2017, 31(2), 253-261.

ISSN 1011-3924

(c) 2017 Chemical Society of Ethiopia and The Authors

Printed in Ethiopia

DOI: http://dx.doi.org/10.4314/bcse.v31i2.7

\title{
SYNTHESIS AND CRYSTAL STRUCTURE OF TRINUCLEAR POTASSIUM(I) COMPLEX WITH OXY-BRIDGED BIS(GEM-DINITRO)FURAZAN AND TRIAMINOGUANIDINIUM
}

\author{
$\mathrm{Li}-\mathrm{Li} \mathrm{An}^{1 *}$ and Qian-Qian $\mathrm{Yu}^{2}$ \\ ${ }^{1}$ School of Chemical Engineering, Northwest University for Nationalities, Lanzhou 730030, \\ China \\ ${ }^{2}$ Shaanxi Institute of Technology, Shaanxi, Xi'an 710301, China
}

(Received April 3, 2016; revised July 19, 2017)

\begin{abstract}
A furazan-based trinuclear potassium(I) complex derived from the oxy-bridged bis(gemdinitro)furazan (OBNF) and triaminoguanidinium (TGA) units was synthesized and characterized by elemental analyses, nuclear magnetic resonance (NMR) and infrared (IR) spectroscopy. The single crystal X-ray structure of the complex has been determined. It revealed that the asymmetric unit contains two crystallographically independent $\mathrm{OBNF}^{2-}$ anion, one triaminoguanidinium cation, three potassium cations $\left(\mathrm{K}^{+}\right)$and one crystallized water molecule. In the crystal structure, intra- and intermolecular hydrogen bonding interactions as well as weak $\pi-\pi$ stacking interactions were observed, which are beneficial to form the net-like structure.
\end{abstract}

KEY WORDS: Trinuclear potassium(I) complex, Oxy-bridged bis(gem-dinitro)furazan, Triaminoguanidinium, Crystal structure, X-ray diffraction

\section{INTRODUCTION}

Owing to containing abundant $\mathrm{C}-\mathrm{N}, \mathrm{C}=\mathrm{N}$ and $\mathrm{N}-\mathrm{O}$ chemical bonds, furazan ring is an important kind unit for constructing energetic compound. Recently, furazan ring has attracted widely attention due to their high standard enthalpy of formation, high nitrogen content, high energy density, good thermal stability, and low melting point [1-6]. The combination of nitrogen-rich furazan ring with energetic group or backbones containing acidic protons could serve as anions to form energetic compounds. In this regard, compounds such as, nitramine or tetrazole-functionalized based furazan had been investigated and were found to have shown promising performance [7-12]. The gem-dinitro group has been reported as being an effective anion to construct gem-dinitro group containing energetic compounds, with the high value of density contribution of $1.759 \mathrm{~g} \mathrm{~cm}^{-3}$ [13-15]. To the best of our knowledge, the way of introducing gem-dinitro group into furazan ring to construct energetic compound is an effective strategy for developing novel energy material. Thus, herein, we report the synthesis and structural characterization of a furazan-based trinuclear potassium(I) and its X-ray crystal structure is also investigated.

\section{EXPERIMENTAL}

\section{Material and measurements}

All reagents, unless otherwise specified, were obtained from the J\&K Chemical Co. LTD in analytical-grade. The material oxy-bridged bis(gem-dinitro)furazan (OBNF) was synthesized according to the reported procedure $[15,16]$.

NMR $\left({ }^{1} \mathrm{H}\right.$ and $\left.{ }^{13} \mathrm{C}\right)$ were obtained on a Bruker AV500 NMR spectrometer and referred to tetramethylsilane (TMS). Chemical shifts were reported in ppm and splitting patterns were designed as $\mathrm{s}$ (singlet), $\mathrm{d}$ (doublet), $\mathrm{t}$ (triplet), $\mathrm{m}$ (multiplet), and br (broaden). Infrared spectra were obtained on a Nicolet NEXUS870 Infrared spectrometer in the range of 4000-400 $\mathrm{cm}^{-1}$, using $\mathrm{KBr}$ pellets. Elemental analyses $(\mathrm{C}, \mathrm{H}$ and $\mathrm{N}$ ) were recorded on a VARI-El-3 elemental analyzer.

*Corresponding author. E-mail: anlili2011@163.com

This work is licensed under the Creative Commons Attribution 4.0 International License 
Synthesis of dipotassium oxy-bridged bis (gem-dinitro)furazan (1)

Potassium hydroxide $(0.224 \mathrm{~g}, 4 \mathrm{mmol})$ was added to a solution of OBNF $(0.724 \mathrm{~g}, 2 \mathrm{mmol})$ in $10 \mathrm{~mL}$ methanol. After stirring for $1 \mathrm{~h}$ at room temperature, $0.809 \mathrm{~g}$ (yield: $92.3 \%$ ) yellow precipitate was filtered off. Analysis: found: C $16.34 \%, \mathrm{~N} 25.67 \%$; calculated for $\mathrm{C}_{6} \mathrm{~K}_{2} \mathrm{~N}_{8} \mathrm{O}_{11}$ : C $16.44 \%$, N 25.57\%. IR data (cm $\left.{ }^{-1}, \mathrm{KBr}\right): 1589,1526,1479,1239,1070,997 .{ }^{13} \mathrm{C}$ NMR (DMSO$\left.d_{6}, 125 \mathrm{MHz}, \mathrm{ppm}\right): \delta 160.77,142.31,118.67$.

Synthesis of potassium triaminoguanidinium oxy-bridged bis(gem-dinitro)furazan (2)

A solution of $\mathrm{AgNO}_{3}(0.085 \mathrm{~g}, 0.5 \mathrm{mmol})$ in $10 \mathrm{~mL}$ water was added to a solution of $\mathbf{1}(0.438 \mathrm{~g}$, $1 \mathrm{mmol}$ ) in $10 \mathrm{~mL}$ water. After stirring for $0.5 \mathrm{~h}$ at room temperature, triaminoguanidinium chloride $(0.070 \mathrm{~g}, 0.5 \mathrm{mmol})$ was added. The resulting mixture was stirred at $60{ }^{\circ} \mathrm{C}$ for an additional $1 \mathrm{~h}$. After removal of the $\mathrm{AgCl}$ precipitate, the solution was evaporated in vacuo and the target product (yellow crystals) was obtained (Yield: 60.1\%). Analysis: found: $\mathrm{C} 16.16, \mathrm{H}$ 0.75, N 32.35; calculated for $\mathrm{C}_{13} \mathrm{H}_{8} \mathrm{~K}_{3} \mathrm{~N}_{22} \mathrm{O}_{23}$ : C 16.30, H 0.84, N 32.18. IR data $\left(\mathrm{cm}^{-1}, \mathrm{KBr}\right)$ : $3464,3369,3321,1671,1540,1479,1389,1325,1238,1141,999,963,868,823,747 .{ }^{1} \mathrm{H}$ NMR (500 MHz, $d_{6}$-DMSO, ppm): $\delta 8.59(\mathrm{~s} .3 \mathrm{H}, \mathrm{NH}), 4.49\left(\mathrm{~s}, 6 \mathrm{H}, \mathrm{NH}_{2}\right) .{ }^{13} \mathrm{CNMR}(125 \mathrm{MHz}$, DMSO- $\left.d_{6}, \mathrm{ppm}\right): \delta 161.1,159.4,142.6,119.0$.

Table 1. Crystallographic data and experimental details for potassium complex.

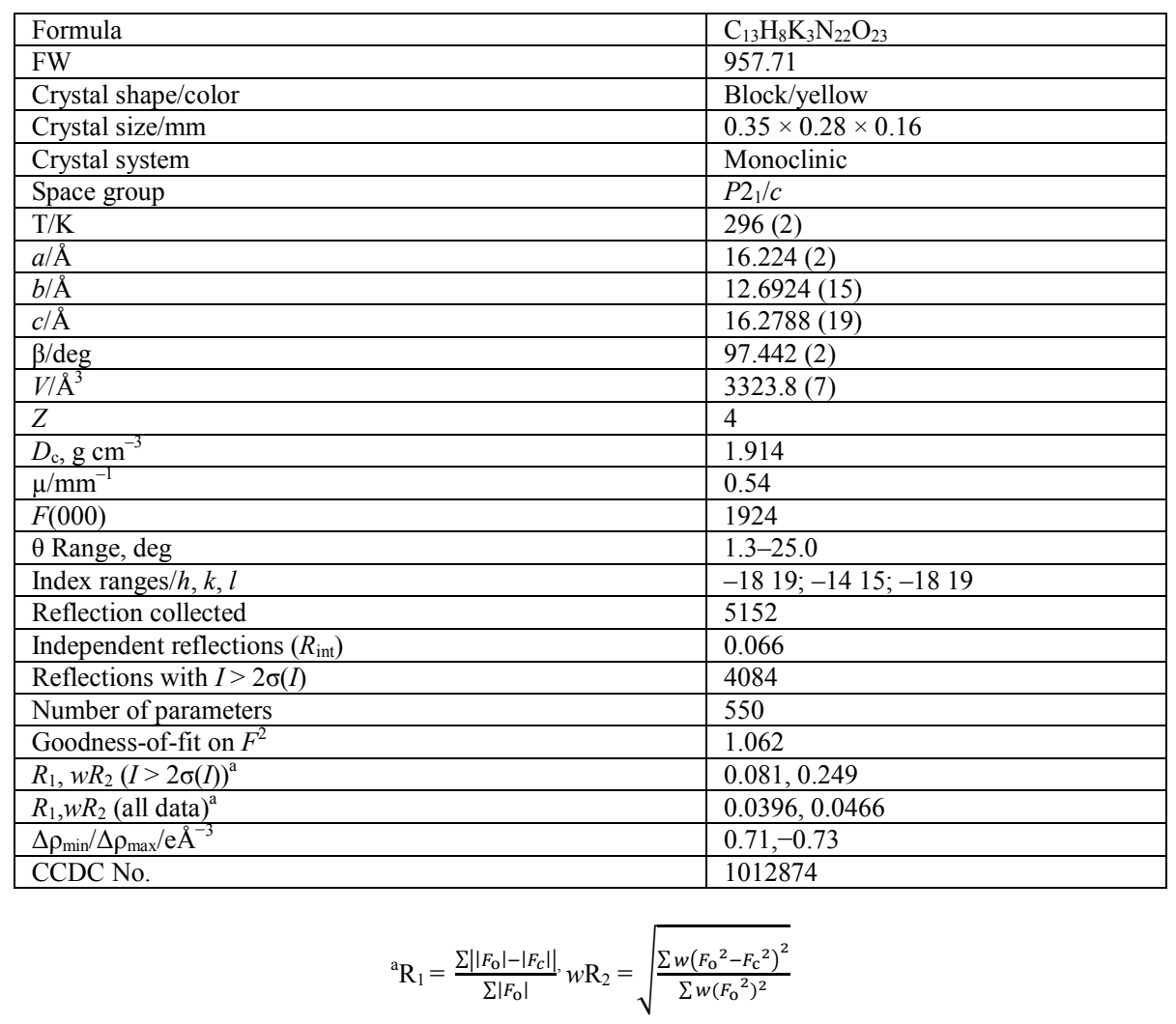

Bull. Chem. Soc. Ethiop. 2017, 31(2) 
Table 2. Selected bond lengths $(\AA)$ and angles (deg) for the potassium complex.

\begin{tabular}{|c|c|c|c|c|c|}
\hline Bond length & $\mathrm{d}, \AA$ & Bond length & $\mathrm{d}, \AA$ & Bond length & $\mathrm{d}, \AA$ \\
\hline K1-O1 & $2.758(6)$ & $\mathrm{K} 1-\mathrm{O} 3$ & $2.772(6)$ & K1-O9 & $2.838(5)$ \\
\hline $\mathrm{K} 1-\mathrm{O} 22^{\mathrm{i}}$ & $2.885(5)$ & $\mathrm{K} 1-\mathrm{O} 12^{\mathrm{ii}}$ & $2.889(5)$ & $\mathrm{K} 1-\mathrm{O} 3^{\mathrm{ii}}$ & $2.967(6)$ \\
\hline $\mathrm{K} 1-\mathrm{O} 13^{\mathrm{ii}}$ & $2.991(6)$ & $\mathrm{K} 1-\mathrm{O} 4^{\mathrm{ii}}$ & $3.027(5)$ & $\mathrm{K} 1-\mathrm{N} 6^{\mathrm{i}}$ & $3.143(6)$ \\
\hline $\mathrm{K} 2-\mathrm{O}^{111}$ & $2.722(6)$ & $\mathrm{K} 2-\mathrm{O} 20^{1 \mathrm{~V}}$ & $2.858(5)$ & K2-O10 & $2.868(5)$ \\
\hline K2-O9 & $2.881(6)$ & $\mathrm{K} 2-\mathrm{O} 19^{\mathrm{iv}}$ & $2.962(5)$ & $\mathrm{K} 2-\mathrm{O} 22^{\mathrm{i}}$ & $3.030(5)$ \\
\hline $\mathrm{K} 2-\mathrm{O} 4^{11}$ & $3.165(6)$ & $\mathrm{K} 3-\mathrm{O} 13^{1 \mathrm{~V}}$ & $2.691(5)$ & $\mathrm{K} 3-\mathrm{O} 20$ & $2.743(5)$ \\
\hline $\mathrm{K} 3-\mathrm{O}^{111}$ & $2.804(5)$ & $\mathrm{K} 3-\mathrm{O} 14^{1 \mathrm{~V}}$ & $2.827(7)$ & K3-O11 & $2.912(7)$ \\
\hline $\mathrm{K} 3-\mathrm{O} 21$ & $2.957(6)$ & $\mathrm{K} 3-\mathrm{O} 10^{1 \mathrm{v}}$ & $2.995(5)$ & $\mathrm{K} 3-\mathrm{K} 2^{\mathrm{iv}}$ & $4.522(2)$ \\
\hline Bond angle & $\omega$, deg & Bond angle & $\omega, \operatorname{deg}$ & Bond angle & $\omega, \operatorname{deg}$ \\
\hline O1-K1-O3 & $56.01(16)$ & O1-K1-O9 & $98.09(17)$ & O3-K1-O9 & $80.08(19)$ \\
\hline O1-K1-O22 ${ }^{1}$ & $122.07(16)$ & O3-K1-O22 ${ }^{1}$ & $162.46(18)$ & O9-K1-O22 ${ }^{1}$ & $83.17(17)$ \\
\hline O1-K1-O12 ${ }^{\text {ii }}$ & $113.93(17)$ & O3-K1-O12 & $104.74(17)$ & O9-K1-O12 ${ }^{\mathrm{ii}}$ & $144.49(15)$ \\
\hline $\mathrm{O} 22^{\mathrm{i}}-\mathrm{K} 1-\mathrm{O} 12^{\mathrm{ii}}$ & $91.92(16)$ & $\mathrm{O} 1-\mathrm{K} 1-\mathrm{O} 3^{\mathrm{ii}}$ & $128.86(16)$ & $\mathrm{O} 3-\mathrm{K} 1-\mathrm{O} 3^{\mathrm{ii}}$ & $74.74(19)$ \\
\hline O9-K1-O3 ${ }^{11}$ & $57.35(15)$ & $\mathrm{O} 22^{1}-\mathrm{K} 1-\mathrm{O} 3^{11}$ & $100.42(16)$ & $\mathrm{O} 12^{11}-\mathrm{K} 1-\mathrm{O} 3^{11}$ & $89.43(15)$ \\
\hline O1-K1-O13 ${ }^{\text {ii }}$ & $70.90(16)$ & O3-K1-O13 & $82.02(17)$ & O9-K1-O13 & $162.07(16)$ \\
\hline $\mathrm{O} 22^{\mathrm{i}}-\mathrm{K} 1-\mathrm{O} 13^{\mathrm{ii}}$ & $114.58(15)$ & $\mathrm{O} 12^{\mathrm{ii}}-\mathrm{K} 1-\mathrm{O} 13^{\mathrm{ii}}$ & $43.05(14)$ & $\mathrm{O} 3^{\mathrm{ii}}-\mathrm{K} 1-\mathrm{O} 13^{\mathrm{ii}}$ & $118.15(17)$ \\
\hline $\mathrm{O} 1-\mathrm{K} 1-\mathrm{O} 4^{\mathrm{ii}}$ & $168.00(17)$ & O3-K1-O4 ${ }^{\text {ii }}$ & $112.62(16)$ & O9-K1-O4 $4^{\mathrm{ii}}$ & $82.48(15)$ \\
\hline $\mathrm{O} 22^{\mathrm{i}}-\mathrm{K} 1-\mathrm{O} 4^{\mathrm{ii}}$ & 69.93(13) & $\mathrm{O} 12^{\mathrm{ii}}-\mathrm{K} 1-\mathrm{O} 4^{\mathrm{ii}}$ & $62.98(15)$ & $\mathrm{O} 3^{\mathrm{ii}}-\mathrm{K} 1-\mathrm{O} 4^{\mathrm{ii}}$ & $42.12(14)$ \\
\hline $\mathrm{O} 13^{\mathrm{ii}}-\mathrm{K} 1-\mathrm{O} 4^{\mathrm{ii}}$ & $105.33(15)$ & O1-K1-N6 ${ }^{1}$ & $69.83(15)$ & O3-K1-N6 ${ }^{\mathrm{i}}$ & $122.81(17)$ \\
\hline O9-K1-N6 ${ }^{\mathrm{i}}$ & $127.53(16)$ & $\mathrm{O} 22^{\mathrm{i}}-\mathrm{K} 1-\mathrm{N} 6^{\mathrm{i}}$ & 64.84(14) & $\mathrm{O} 12^{\mathrm{i}}-\mathrm{K} 1-\mathrm{N} 6^{\mathrm{i}}$ & $80.04(15)$ \\
\hline $\mathrm{O} 3^{\mathrm{ii}}-\mathrm{K} 1-\mathrm{N} 6^{\mathrm{i}}$ & $161.28(16)$ & $\mathrm{O} 13^{\mathrm{i}}-\mathrm{K} 1-\mathrm{N} 6^{\mathrm{i}}$ & $63.09(15)$ & $\mathrm{O} 4^{\mathrm{ii}}-\mathrm{K} 1-\mathrm{N} 6^{\mathrm{i}}$ & $119.27(15)$ \\
\hline $\mathrm{O} 2^{\mathrm{ii1}}-\mathrm{K} 2-\mathrm{O} 20^{\mathrm{iv}}$ & $131.95(19)$ & $\mathrm{O} 2^{\mathrm{iii}}-\mathrm{K} 2-\mathrm{O} 10$ & $68.76(18)$ & $\mathrm{O} 20^{\mathrm{iv}}-\mathrm{K} 2-\mathrm{O} 10$ & $75.86(14)$ \\
\hline $\mathrm{O} 2^{111}-\mathrm{K} 2-\mathrm{O} 9$ & $84.35(18)$ & $\mathrm{O} 20^{1 \mathrm{v}}-\mathrm{K} 2-\mathrm{O} 9$ & $100.11(15)$ & O10-K2-O9 & $53.65(15)$ \\
\hline $\mathrm{O} 2^{\mathrm{iii}}-\mathrm{K} 2-\mathrm{O} 19^{\mathrm{iv}}$ & $125.6(2)$ & $\mathrm{O} 20^{\mathrm{iv}}-\mathrm{K} 2-\mathrm{O} 19^{\mathrm{iv}}$ & $43.57(13)$ & $\mathrm{O} 10-\mathrm{K} 2-\mathrm{O} 19^{\mathrm{iv}}$ & $111.42(15)$ \\
\hline O9-K2-O199 & $142.15(16)$ & $\mathrm{O} 2^{\mathrm{ii1}}-\mathrm{K} 2-\mathrm{O} 22^{\mathrm{i}}$ & $94.74(18)$ & $\mathrm{O} 20^{\mathrm{iv}}-\mathrm{K} 2-\mathrm{O} 22^{\mathrm{i}}$ & $133.26(15)$ \\
\hline $\mathrm{O} 10-\mathrm{K} 2-\mathrm{O} 22^{\mathrm{i}}$ & $131.07(15)$ & O9-K2-O22 & $79.92(15)$ & $\mathrm{O} 19^{\mathrm{iv}}-\mathrm{K} 2-\mathrm{O} 22^{\mathrm{i}}$ & $115.20(15)$ \\
\hline $\mathrm{O} 2^{\mathrm{iii}}-\mathrm{K} 2-\mathrm{O} 4^{\mathrm{ii}}$ & $156.84(18)$ & $\mathrm{O} 20^{\mathrm{iv}}-\mathrm{K} 2-\mathrm{O} 4^{\mathrm{ii}}$ & 67.81(13) & $\mathrm{O} 10-\mathrm{K} 2-\mathrm{O} 4^{\mathrm{ii}}$ & $112.85(16)$ \\
\hline $\mathrm{O} 9-\mathrm{K} 2-\mathrm{O} 4^{\mathrm{i1}}$ & $79.43(15)$ & $\mathrm{O} 19^{\mathrm{iv}}-\mathrm{K} 2-\mathrm{O} 4^{\mathrm{in}}$ & $76.37(16)$ & $\mathrm{O} 22^{\mathrm{i}}-\mathrm{K} 2-\mathrm{O} 4^{\mathrm{ii}}$ & $66.31(13)$ \\
\hline $\mathrm{O} 13^{\mathrm{iv}}-\mathrm{K} 3-\mathrm{O} 20$ & $113.94(17)$ & 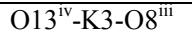 & $85.45(16)$ & $\mathrm{O} 20-\mathrm{K} 3-\mathrm{O} 8^{111}$ & $114.75(15)$ \\
\hline $\mathrm{O} 13^{\mathrm{IV}}-\mathrm{K} 3-\mathrm{O} 14^{\mathrm{IV}}$ & $56.51(17)$ & $\mathrm{O} 20-\mathrm{K} 3-\mathrm{O} 14^{\mathrm{IV}}$ & $160.02(19)$ & $\mathrm{O} 8^{111}-\mathrm{K} 3-\mathrm{O} 14^{\mathrm{IV}}$ & $83.3(2)$ \\
\hline $\mathrm{O} 13^{\mathrm{IV}}-\mathrm{K} 3-\mathrm{O} 11$ & $157.98(19)$ & O20-K3-O11 & $63.50(15)$ & $\mathrm{O} 8^{111}-\mathrm{K} 3-\mathrm{O} 11$ & $115.93(17)$ \\
\hline $\mathrm{O} 14^{1 \mathrm{v}}-\mathrm{K} 3-\mathrm{O} 11$ & $117.80(19)$ & $\mathrm{O} 13^{\mathrm{iv}}-\mathrm{K} 3-\mathrm{O} 21$ & $124.11(18)$ & O20-K3-O21 & $53.99(15)$ \\
\hline $\mathrm{O} 8^{\mathrm{iii}}-\mathrm{K} 3-\mathrm{O} 21$ & $63.51(15)$ & $\mathrm{O} 14^{\mathrm{iv}}-\mathrm{K} 3-\mathrm{O} 21$ & $145.8(2)$ & O11-K3-O21 & $73.57(18)$ \\
\hline $\mathrm{O} 13^{\mathrm{iv}}-\mathrm{K} 3-\mathrm{O} 10^{\mathrm{iv}}$ & $72.88(16)$ & $\mathrm{O} 20-\mathrm{K} 3-\mathrm{O} 10^{\mathrm{iv}}$ & $75.52(14)$ & $\mathrm{O} 8^{\mathrm{iii}}-\mathrm{K} 3-\mathrm{O} 10^{\mathrm{iv}}$ & $158.33(15)$ \\
\hline $\mathrm{O} 14^{\mathrm{iv}}-\mathrm{K} 3-\mathrm{O} 10^{\mathrm{iv}}$ & $84.63(19)$ & O11-K3-O10 ${ }^{\mathrm{iv}}$ & $85.64(17)$ & $\mathrm{O} 21-\mathrm{K} 3-\mathrm{O} 10^{\mathrm{iv}}$ & $129.51(16)$ \\
\hline
\end{tabular}

Symmetry codes: (i) $-x+1, y+1 / 2,-z+1 / 2$; (ii) $-x+1,-y+2,-z$; (iii) $-x+1, y-1 / 2,-z+1 / 2$; (iv) $-x+1,-y+1$, $-z$.

\section{$X$-ray structure determination}

Single crystal X-ray diffraction data were collected at 296(2) K on a Bruker APEX-II CCD diffractometer with graphite monochromated Mo-Ka radiation $(\lambda=0.71073 \AA)$. Suitable crystal was affixed to the end of glass fibers using silicone grease and transferred to the goniostat. The unit cell parameters were obtained from SAINT; absorption corrections were performed with SADABS [17]. The structure was solved by direct methods and refined by the full-matrix leastsquares method on $F^{2}$ using the SHELXTL crystallographic software package [18]. The nonhydrogen atoms were refined anisotropically, hydrogen atoms were positioned geometrically $(\mathrm{N}-\mathrm{H}=0.86 \AA)$ and were refined as riding, with $\mathrm{U}_{\mathrm{iso}}(\mathrm{H})=1.20 \mathrm{U}_{\mathrm{eq}}(\mathrm{N})$. Crystallographic data and experimental details for potassium complex are summarized in Table 1. The selected bond lengths and angles of the potassium complex are given in Table 2. 


\section{RESULTS AND DISCUSSION}

General

The OBNF was synthesized according to the previously reported procedure [15] and further deprotonated and formed the divalent $\mathrm{OBNF}^{2-}$ in the presence of $\mathrm{KOH}$ with the yield of $92.3 \%$. Then, $\mathrm{OBNF}^{2-}$ was reacted with $\mathrm{AgNO}_{3}$ aq., and the $\mathrm{K}^{+}$was replaced by the $\mathrm{Ag}^{+}$. Afterwards, the intermediate reacted with triaminoguanidinium chloride under $60{ }^{\circ} \mathrm{C}$ to afford the potassiumcontaining complex. The obtained complex was confirmed by elemental analysis, IR, NMR $\left({ }^{1} \mathrm{H}\right.$ and ${ }^{13} \mathrm{C}$ ) spectra. These preliminary measurements indicated that $\mathrm{OBNF}^{2-}$ anion and the second ligand triaminoguanidinium $\left(\mathrm{TAG}^{+}\right)$cation all coordinated to $\mathrm{K}$ ion center. Furthermore, the complex are soluble in methanol, ethanol, $N, N$-dimethylformide (DMF), dimethyl sulfoxide (DMSO) high polar solvents.<smiles>Cc1nonc1Oc1nonc1[N+](=O)[O-]</smiles><smiles>NNC(NN)NN</smiles>

Scheme 1. Synthesis of the potassium(I) complex.

IR spectra

It was noted that the IR spectrum of the complex was consistent with the structure as determined by X-ray diffraction. The absorption bands at approximately 3464, 3369, 3321, 999, 963, 868, 823 and $747 \mathrm{~cm}^{-1}$ are observed, which are similar to the complexes [15]. The absorption bands in the range of $3500-3300 \mathrm{~cm}^{-1}$ are assigned to the symmetric $\mathrm{N}-\mathrm{H}$ stretching vibrational models of the nitrogen-rich cations. Furthermore, peaks at 1671, 1540, 1479, 1389, 1325, 1238, $1141 \mathrm{~cm}^{-1}$ are attributed to $\mathrm{C}=\mathrm{N}$ and $\mathrm{NO}_{2}$ bonds vibrational models and peaks placed at 999 , $963,868,823$ and $747 \mathrm{~cm}^{-1}$ can be assigned to $\mathrm{C}-\mathrm{N}$ and $\mathrm{K}-\mathrm{O}$ bond stretching vibrations model [7,19-21].

\section{NMR analysis}

As shown in Figure 1a, proton signal $(\delta 8.59)$ of compound 2 can be attributed to the $-\mathrm{NH}-$ in the cation triaminoguanidinium $\left(\mathrm{TAG}^{+}\right)$, while another proton signal $(4.49 \mathrm{ppm})$ could ascribe to $-\mathrm{NH}_{2}$ of the $\mathrm{TAG}^{+}$. And these two protons with a ratio of $1: 2$, indicating the $\mathrm{TAG}^{+}$cation was existed in the compound 2. Furthermore, in ${ }^{13} \mathrm{C}$ NMR spectra (Fig. 1b), three signals at 161.1, 142.7 and $119.0 \mathrm{ppm}$ can attribute to $\mathrm{O}-\mathbf{C}=\mathrm{N}-,-\mathrm{N}=\mathbf{C C}\left(\mathrm{NO}_{2}\right)_{2}$ and $\mathbf{C}\left(\mathrm{NO}_{2}\right)_{2}$ of the $\mathrm{OBNF}^{2-}$ anion, which are close to the reported data [21]. It suggested that $\mathrm{OBNF}^{2-}$ anion existed in the complex. And another $159.4 \mathrm{ppm}$ signal is related to the $\mathbf{C}\left(\mathrm{NHNH}_{2}\right)_{3}$ cation. It was noted that the ${ }^{13} \mathrm{C}$ NMR signal of gem-dinitro group carbon $\left(\mathrm{C}\left(\mathrm{NO}_{2}\right)\right)$ at $119.0 \mathrm{ppm}$ appeared at higher field compared to the ones in literature (129 to $132 \mathrm{ppm}$ ) [22-24], which resulted from the conjugation of negative charge throughout the aromatic rings [21]. 

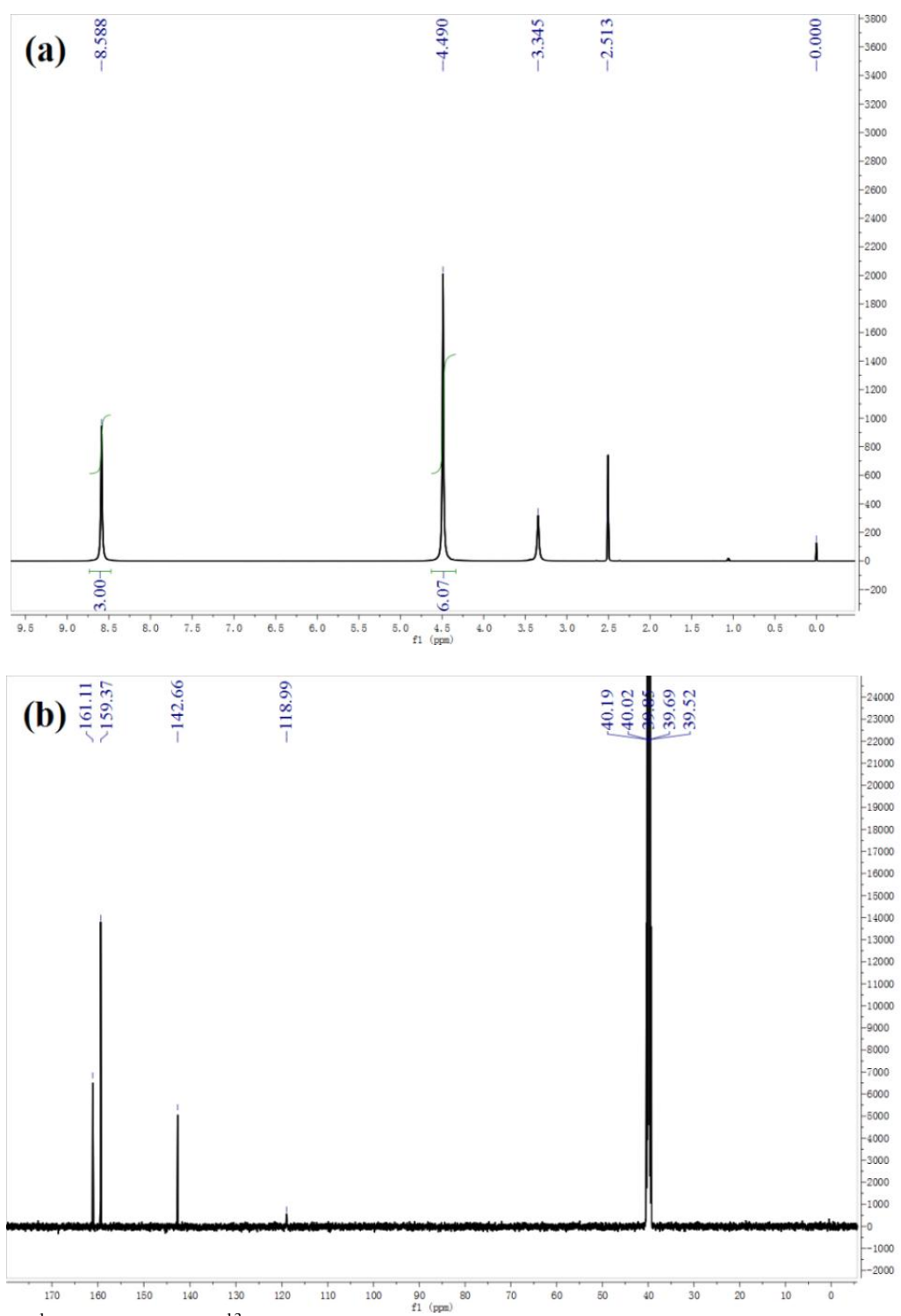

Figure 1. ${ }^{1} \mathrm{H}$ NMR (a) and ${ }^{13} \mathrm{C}$ NMR (b) spectra for the potassium(I) complex in DMSO- $d_{6}$.

\section{Structure description of the complex}

Complex 2 crystallizes in the monoclinic space group $P 2_{1} / c$ with calculated density of $1.914 \mathrm{~g}$ $\mathrm{cm}^{-3}$. The asymmetric unit contains two crystallographically independent deprotonated $\mathrm{OBNF}^{2-}$ anion, one triaminoguanidinium $\left(\mathrm{TAG}^{+}, \mathrm{C}\left(\mathrm{NHNH}_{2}\right)_{2}(\mathrm{NHNH})^{+}\right)$cation, three potassium cation $\left(\mathrm{K}^{+}\right)$and one crystallized water molecule. As to the anion, the bridged oxygen atom is nearly coplanar with both furazan rings (torsion angle O6-C3-C2-N3 174.74 ${ }^{\circ}$, O6-C4-C5-N6 $179.184^{\circ}$, O17-C9-C8-N11 $178.16^{\circ}$ and O17-C10-C11-N14 $\left.179.66^{\circ}\right)$. The dihedral angle 
between two furazan ring planes (defined by $\mathrm{C} 2 \mathrm{C} 3 \mathrm{~N} 4 \mathrm{O} 5 \mathrm{~N} 3$ and $\mathrm{C} 5 \mathrm{C} 4 \mathrm{~N} 5 \mathrm{O} 7 \mathrm{~N} 6$ ) between two furazan ring planes is $33.48^{\circ}$, while one (defined by $\mathrm{C} 8 \mathrm{C} 9 \mathrm{~N} 11 \mathrm{O} 16 \mathrm{~N} 12$ and $\mathrm{C} 10 \mathrm{C} 11 \mathrm{~N} 13 \mathrm{O} 18 \mathrm{~N} 14)$ is only $14.48^{\circ}$, which are similar to the reported oxy-bridged furazan structures [15]. The length of the $\mathrm{C}-\mathrm{C}$ bonds $(\mathrm{C} 2-\mathrm{C} 3, \mathrm{C} 4-\mathrm{C} 5, \mathrm{C} 8-\mathrm{C} 9$ and $\mathrm{C} 10-\mathrm{C} 11)$ connecting gem-dinitro and furazan ring are $1.420,1.426,1.420$ and $1.422 \AA$, respectively. These bond data are between $\mathrm{C}-\mathrm{C}$ single bond $(1.530 \AA)$ and $\mathrm{C}=\mathrm{C}$ double bond $(1.320 \AA)$ [25]. These might indicate conjugation of negative charge throughout the aromatic rings [15, 21].
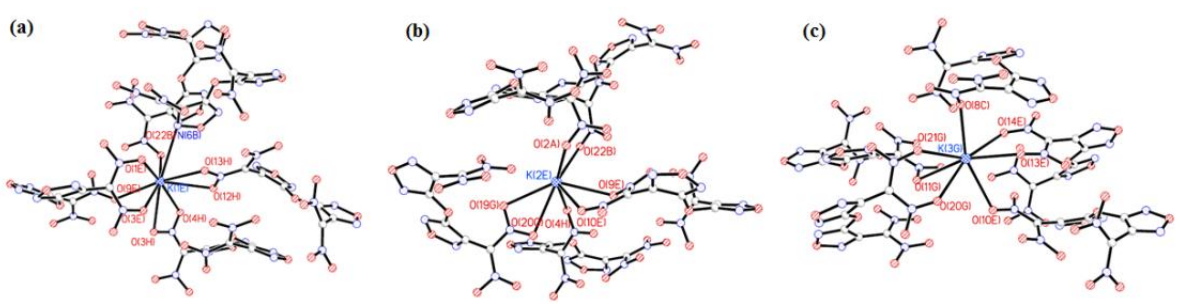

Figure 2. The coordination environments of $\mathrm{K}(1)^{+}$ion (a), $\mathrm{K}(2)^{+}$ion (b) and $\mathrm{K}(3)^{+}$ion (c) in the complex. Thermal ellipsoids are drawn at the $30 \%$ probability level and hydrogen atoms are omitted for clarity.

Table 3. Hydrogen bonding distances $(\AA)$ and bond angles (deg) for complex.

\begin{tabular}{|c|c|c|c|c|}
\hline $\mathrm{D}-\mathrm{H} \cdots \mathrm{A}$ & $\mathrm{D}-\mathrm{H}, \AA$ & $\mathrm{H} \cdots \mathrm{A}, \AA$ & $\mathrm{D} \cdots \mathrm{A}, \AA$ & $\mathrm{D}-\mathrm{H} \cdots \mathrm{A}, \operatorname{deg}$ \\
\hline $\mathrm{N} 17-\mathrm{H} 17 \cdots \mathrm{N} 21$ & 0.86 & 2.53 & $2.818(11)$ & 101 \\
\hline $\mathrm{N} 19-\mathrm{H} 9 \mathrm{~A} \cdots \mathrm{N} 22$ & 0.86 & 2.47 & $2.754(11)$ & 100 \\
\hline $\mathrm{N} 20-\mathrm{H} 20 \cdots \mathrm{N} 17$ & 0.86 & 2.34 & $2.671(9)$ & 103 \\
\hline $\mathrm{N} 22-\mathrm{H} 22 \cdots \mathrm{N} 19$ & 0.86 & 2.42 & $2.754(11)$ & 104 \\
\hline $\mathrm{N} 17-\mathrm{H} 17 \cdots \mathrm{O}^{1}$ & 0.86 & 2.32 & $3.085(9)$ & 149 \\
\hline $\mathrm{N} 18-\mathrm{H} 18 \cdots \mathrm{O} 23^{\text {ii }}$ & 0.86 & 2.06 & $2.912(11)$ & 170 \\
\hline $\mathrm{N} 19-\mathrm{H} 19 \mathrm{~B} \cdots \mathrm{O} 12^{\text {iii }}$ & 0.86 & 2.53 & $3.215(9)$ & 137 \\
\hline $\mathrm{N} 19-\mathrm{H} 19 \mathrm{~B} \cdots \mathrm{N} 11^{\text {iii }}$ & 0.86 & 2.46 & $2.911(9)$ & 114 \\
\hline $\mathrm{N} 20-\mathrm{H} 20 \cdots \mathrm{O} 22^{\text {iv }}$ & 0.86 & 2.28 & $3.059(8)$ & 151 \\
\hline $\mathrm{N} 21-\mathrm{H} 21 \mathrm{~A} \cdots \mathrm{O} 23^{\text {ii }}$ & 0.86 & 2.45 & $3.235(13)$ & 153 \\
\hline $\mathrm{N} 21-\mathrm{H} 21 \mathrm{~B} \cdots \mathrm{N} 12^{\mathrm{v}}$ & 0.86 & 2.38 & $3.156(10)$ & 151 \\
\hline $\mathrm{N} 21-\mathrm{H} 21 \mathrm{~B} \cdots \mathrm{N} 13^{\mathrm{v}}$ & 0.86 & 2.58 & $3.178(12)$ & 127 \\
\hline
\end{tabular}

Symmetry codes: (i) $1-\mathrm{x},-1 / 2+\mathrm{y}, 1 / 2-\mathrm{z}$; (ii) $-\mathrm{x}, 1-\mathrm{y},-\mathrm{z}$; (iii) $1-\mathrm{x}, 2-\mathrm{y},-\mathrm{z}$; (iv) $1-\mathrm{x}, 1 / 2+\mathrm{y}, 1 / 2-\mathrm{z}$; (v) $-1+\mathrm{x}, 3 / 2-\mathrm{y},-1 / 2+\mathrm{z}$.

As shown in Figure 2, there are different coordination environment for the three potassium central ions. For the potassium cation $\left(\mathrm{K}(1)^{+}\right)$, the potassium ion is nona-coordinated by eight nitro oxygen atoms $\left(\mathrm{O}(1), \mathrm{O}(3), \mathrm{O}(9), \mathrm{O}(22)^{\mathrm{i}}, \mathrm{O}(3)^{\mathrm{ii}}, \mathrm{O}(4)^{\mathrm{ii}}, \mathrm{O}(12)^{\mathrm{ii}}, \mathrm{O}(13)^{\mathrm{ii}}\right)$ and furazan nitrogen atom $\left(\mathrm{N}(6)^{\mathrm{i}}\right)$ from the $\mathrm{OBNF}^{2-}$ anion, and connects with five adjacent $\mathrm{OBNF}^{2-}$ anions through eight $\mathrm{K}-\mathrm{O}$ coordination bonds $\left[\mathrm{K}(1)-\mathrm{O}(1), \mathrm{K}(1)-\mathrm{O}(3)\right.$ and $\mathrm{K}(1)-\mathrm{O}(9) ; \mathrm{K}(1)-\mathrm{O}(22)^{\mathrm{i}}$; $\mathrm{K}(1)-\mathrm{O}(3)^{\mathrm{ii}}$ and $\mathrm{K}(1)-\mathrm{O}(4)^{\mathrm{ii}} ; \mathrm{K}(1)-\mathrm{O}(12)^{\mathrm{ii}}$ and $\mathrm{K}(1)-\mathrm{O}(13)^{\mathrm{ii}}$ from four different $\mathrm{OBNF}^{2-}$ anions, the bond distance are between 2.758 and $3.027 \AA]$ and one $\mathrm{K}-\mathrm{N}$ coordination bond $\left[\mathrm{K}(1)-\mathrm{N}(6)^{\mathrm{i}}\right.$ from one $\mathrm{OBNF}^{2-}$ anion, $3.143 \AA$ ] (Figure 2a, Table 2). The atoms involved coordination formed a distorted tetradecahedron with potassium ion as coordinate center, atom $\mathrm{N}(6)^{\mathrm{i}}$ and $\mathrm{O}(3)^{\mathrm{ii}}$ in the axis position and other seven oxygen atoms at the equatorial plane (the bond angle of $\mathrm{N}(6)^{\mathrm{i}}-\mathrm{K}(1)-\mathrm{O}(3)^{\mathrm{ii}}$ is $\left.161.28^{\circ}\right)$. For the potassium cation $\left(\mathrm{K}(2)^{+}\right)$, the potassium ion is heptacoordinated by seven nitro oxygen atoms $\left(\mathrm{O}(2)^{\mathrm{iii}}, \mathrm{O}(22)^{\mathrm{i}}, \mathrm{O}(19)^{\mathrm{iv}}, \mathrm{O}(20)^{\mathrm{iv}}, \mathrm{O}(20)^{\mathrm{iv}}, \mathrm{O}(4)^{\mathrm{ii}}, \mathrm{O}(9)\right.$ 
and $\mathrm{O}(10))$ from $\mathrm{OBNF}^{2-}$ anions, and connects with five adjacent $\mathrm{OBNF}^{2-}$ anions through seven $\mathrm{K}-\mathrm{O}$ coordination bonds $\left[\mathrm{K}(2)-\mathrm{O}(2)^{\mathrm{iii}} ; \mathrm{K}(2)-\mathrm{O}(22)^{\mathrm{i}} ; \mathrm{K}(2)-\mathrm{O}(19)^{\mathrm{iv}}\right.$ and $\mathrm{K}(2)-\mathrm{O}(20)^{\mathrm{iv}} ; \mathrm{K}(2)-$ $\mathrm{O}(4)^{\mathrm{ii}} ; \mathrm{K}(2)-\mathrm{O}(9)$ and $\mathrm{K}(2)-\mathrm{O}(10)$ from five different $\mathrm{OBNF}^{2-}$ anions, the bond distance are between 2.722 and $3.165 \AA$ ] (Figure 2b, Table 2). Interestingly, it was observed that there exist an weak K-N coordinating bond $\left[\mathrm{K}(3)-\mathrm{N}(17)^{\mathrm{i}}, 3.214(7) \AA\right]$, which linked the central potassium cation and the second ligand $\mathrm{TAG}^{+}$. For the potassium cation $\left(\mathrm{K}(3)^{+}\right)$, the potassium ion is hepta-coordinated by seven nitro oxygen atoms $\left(\mathrm{O}(8)^{\mathrm{iii}}, \mathrm{O}(11), \mathrm{O}(21)^{\mathrm{i}}, \mathrm{O}(20), \mathrm{O}(10)^{\mathrm{iv}}, \mathrm{O}(13)^{\mathrm{iv}}\right.$ and $\left.\mathrm{O}(14)^{\mathrm{iv}}\right)$ from $\mathrm{OBNF}^{2-}$ anions, and connects with five adjacent $\mathrm{OBNF}^{2-}$ anions through seven $\mathrm{K}-\mathrm{O}$ coordination bonds $\left[\mathrm{K}(3)-\mathrm{O}(8)^{\mathrm{iii}} ; \mathrm{K}(3)-\mathrm{O}(11) ; \mathrm{K}(3)-\mathrm{O}(21)^{\mathrm{i}}\right.$ and $\mathrm{K}(3)-\mathrm{O}(20)$; $\mathrm{K}(3)-$ $\mathrm{O}(10)^{\text {iv }} ; \mathrm{K}(3)-\mathrm{O}(13)^{\text {iv }}$ and $\mathrm{K}(3)-\mathrm{O}(14)^{\mathrm{iv}}$ from five different $\mathrm{OBNF}^{2-}$ anions, 2.743-2.957 $\left.\AA\right]$ (Figure 1c, Table 2). The central atom involved coordination formed a distorted decahedron with potassium ion as coordinate center, atom $\mathrm{O}(8)^{\mathrm{iii}}$ and $\mathrm{O}(10)^{\mathrm{iv}}$ (the bond angle of $\mathrm{N}(6)^{\mathrm{i}}-\mathrm{K}(1)$ $\mathrm{O}(3)^{\mathrm{ii}}$ is $\left.158.33^{\circ}\right)$ in the axis position and other five atoms at the equatorial plane. It was noted that, (i) $\mathrm{K}(1)^{+}$linked the $\mathrm{K}(2)^{+}$via three bridge nitro atoms $\left(\mathrm{O}(22)^{\mathrm{i}}\right.$ and $\left.\mathrm{O}(4)^{\mathrm{ii}}\right)$, (ii) $\mathrm{K}(2)^{+}$linked the $\mathrm{K}(3)^{+}$via two bridge nitro atoms $(\mathrm{O}(10)$ and $\mathrm{O}(20))$, (iii) $\mathrm{K}(1)^{+}$linked the $\mathrm{K}(3)^{+}$via one bridge nitro atoms $(\mathrm{O}(13))$. Also, the weak $\mathrm{K}-\mathrm{O}(3.215-3.402 \AA)$ and $\mathrm{K}-\mathrm{N}$ interaction (3.227$3.350 \AA)$, and metal-metal $\mathrm{K}-\mathrm{K}$ interaction $\left[\mathrm{K}(3)-\mathrm{K}(2)^{\text {iv }}, 4.522 \AA\right]$, which were observed in the similar complex [15]. Furthermore, in the crystal structure of the resultant complex, four intramolecular hydrogen bonding $\mathrm{N}-\mathrm{H} \cdots \mathrm{N} \quad(\mathrm{N} 17-\mathrm{H} 17 \cdots \mathrm{N} 21, \quad \mathrm{~N} 19-\mathrm{H} 9 \mathrm{~A} \cdots \mathrm{N} 22, \quad \mathrm{~N} 20$ $\mathrm{H} 20 \cdots \mathrm{N} 17$ and $\mathrm{N} 22-\mathrm{H} 22 \cdots \mathrm{N} 19)$ interaction and eight intermolecular hydrogen bonding $\mathrm{N}-$ $\mathrm{H} \cdots \mathrm{O}\left(\mathrm{N} 17-\mathrm{H} 17 \cdots \mathrm{O} 5^{\mathrm{i}}, \mathrm{N} 18-\mathrm{H} 18 \cdots \mathrm{O} 23^{\mathrm{ii}}, \mathrm{N} 19-\mathrm{H} 19 \mathrm{~B} \cdots \mathrm{O} 12^{\mathrm{iii}}, \mathrm{N} 20-\mathrm{H} 20 \cdots \mathrm{O} 22^{\mathrm{iv}}\right.$ and $\mathrm{N} 21-$ $\left.\mathrm{H} 21 \mathrm{~A} \cdots \mathrm{O} 23^{\mathrm{ii}}\right), \mathrm{N}-\mathrm{H} \cdots \mathrm{N}\left(\mathrm{N} 19-\mathrm{H} 19 \mathrm{~B} \cdots \mathrm{N} 11^{\mathrm{iii}}, \mathrm{N} 21-\mathrm{H} 21 \mathrm{~B} \cdots \mathrm{N} 12^{\mathrm{v}}, \mathrm{N} 21-\mathrm{H} 21 \mathrm{~B} \cdots \mathrm{N} 13^{\mathrm{v}}\right.$ ) (Figure 3 , Table 3) were existed, and stabilizes the $\mathrm{TAG}^{+}$and adjacent $\mathrm{OBNF}^{2-}$ unit. Besides hydrogen bonding interactions, the weak $\pi-\pi$ interactions (Table 3 ) between the adjacent furazan rings could be also observed, thus further formed the net-like structure.

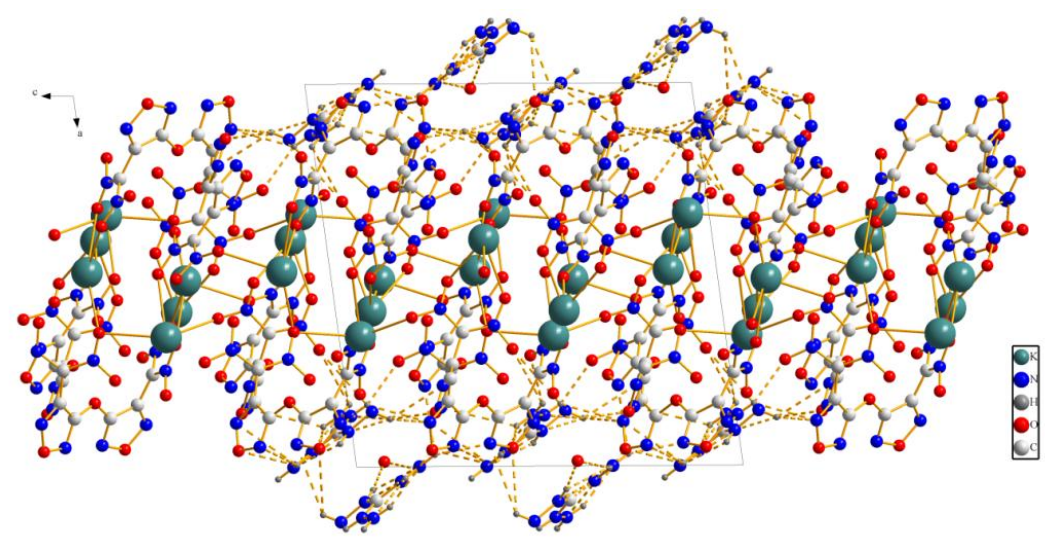

Figure 3. The diagram showing the intra- and intermolecular hydrogen bonding interaction in the complex viewed along the $\mathrm{b}$ axis.

Table 4. $\pi-\pi$ stacking interaction ( $\AA$, deg) for complex.

\begin{tabular}{|c|c|c|c|c|c|}
\hline Ring(I) & Ring(J) & $\alpha$, deg & DCC $(\AA)$ & CgI-prep, $\AA$ & CgJ-prep, $\AA$ \\
\hline $\mathrm{Cg} 2$ & $\mathrm{Cg} 3$ & $15.7(4)$ & $4.331(4)$ & $3.236(3)$ & $3.848(3)$ \\
\hline $\mathrm{Cg} 2$ & $\mathrm{Cg} 4$ & $14.5(4)$ & $4.320(4)$ & $3.154(3)$ & $3.174(3)$ \\
\hline
\end{tabular}

DCC $=$ distance between ring centroids; $\alpha=$ dihedral angle between planes I and J; CgI-perp = perpendicular distance of $\mathrm{Cg}(\mathrm{I})$ from ring $\mathrm{J} ; \mathrm{Cg} 2, \mathrm{Cg} 3$ and $\mathrm{Cg} 4$ for the complex are the centroids of furazan ring O7N5C4C5N6, O16N11C8C9N12 and O18N13C10C11N14.

Bull. Chem. Soc. Ethiop. 2017, 31(2) 


\section{CONCLUSION}

A furazan-based trinuclear potassium(I) complex derived from OBNF and TGA units has been prepared and structurally characterized single crystal X-ray diffraction method, as well as elemental analyses, NMR, IR spectroscopic technique. The symmetric unit contains two crystallographically independent $\mathrm{OBNF}^{2-}$ anion, one triaminoguanidinium cation, three potassium cations $\left(\mathrm{K}^{+}\right)$and one crystallized water molecule. In the crystal structure, intra- and intermolecular hydrogen bonding interactions, weak $\pi-\pi$ stacking interactions were observed.

Supplementary data. The crystallographic data for the structure has been deposited with the Cambridge Crystallographic Data Centre (CCDC No. 1012874). Copies of the data can be obtained free of charge on application to the Director, CCDC, 12 Union Road, Cambridge CB2 1EZ, UK (e-mail for deposition: deposit@ccdc.cam.ac.uk or http://www.ccdc.cam.ac.uk).

\section{ACKNOWLEDGMENTS}

We acknowledge the Fundamental Research Funds for the Central Universities (Grant No.: 31920140103) for supporting this work.

\section{REFERENCES}

1. Coburn, M.D. Picrylamino-substited heterocycles: II furazan. J. Heterocycl. Chem. 1968, 5, 83-87.

2. Sheremetev, A.B.; Lyalin, B.V.; Kozeev, A.M.; Palysaeva, N.V.; Struchkova, M.I.; Suponitsky, K.Y. A practical anodic oxidation of aminofurazans to azofurazans: An environmentally friendly route. $R S C A d v$. 2015, 5, 37617-37625.

3. Shereemetev, A.B.; Yudin, I.L. Advances in the chemistry of furazano[3,4-b]pyrazines and their analogues. Russ. Chem. Rev. 2003, 72, 87-100.

4. Sikder, A.K.; Sikder, N.A. A review of advanced high performance, insensitive and thermally stable energetic materials emerging for military and space applications. J. Hazard. Mater. 2004, 112, 1-15.

5. Wang, B.-Z.; Zhang, G.-F.; Huo, H.; Fan, Y.-J. and Fan, X.-Z. Synthesis, characterization and thermal properties of energetic compounds derived from 3-amino-4-(tetrazol-5-yl) furazan. Chin. J. Chem. 2011, 29, 919-924.

6. Li, X.-Z.; Wang, B.-Z.; Li, H.; Li, Y.-N.; Bi, F.-Q.; Huo, H.; Fan, X.-Z. Novel synthetic route and characterization of $[1,2,5]$ oxadiazolo[3,4-e][1,2,3,4]tetrazine 4,6-di- $N$-oxide (FTDO). Chin. J. Org. Chem. 2012, 32, 1975-1980.

7. Zhang, J.H.; Shreeve, J.M. 3,3'-Dinitroamino-4,4'-azoxyfurazan and its derivatives: an assembly of diverse $\mathrm{N}-\mathrm{O}$ building blocks for high-performance energetic materials. $\mathrm{J}$. Am. Chem. Soc. 2014, 136, 4437-4445.

8. Suponitsky, K.Y.; Lyssenko, K.A.; Antipin, M.Y.; Aleksandrova, N.S.; Sheremetev, A.B. and Novikova, T.S. 4,4'-Bis(nitramino)azofurazan and its salts. Study of molecular and crystal structure based on X-ray and quantum chemical data. Russ. Chem. Bull. Int. Ed. 2009, 58, 2129-2136.

9. Wang, B.-Z.; Li H.; Li, Y.-N.; Lian, P.; Zhang, Y.-S.; Wang X.-J. Review on energetic compounds based on furoxanyl ether. Chin. J. Chem. 2012, 20, 385-390.

10. Li H.; Wang B.-Z.; Lai W.-P.; Wang M-C.; Bi F.-Q.; Ge Z.-X. Synthesis of 3,4-dinitrofuroxan. Chin. J. Energ. Mater. 2013, 21, 396-397.

11. Liang, L.; Huang, H.; Wang, K.; Bian, C.; Song, J.; Ling, L.; Zhao, F. and Zhou, Z. Oxybridged bis( $1 H$-tetrazol-5-yl)furazan and its energetic salts paired with nitrogen-rich cations: highly thermally stable energetic materials with low sensitivity. J. Mater. Chem. 2012, 22, 
21954-21964.

12. An, L.; Yu, Q.; Sun, C. Synthesis and characterization of an energetic compound (E)-4,4'bis(tert-Butyl-N,N,O-azoxy)-3,3'-diazenofurazan. Asian J. Chem. 2013, 25, 8991-8993.

13. Klapötke, T.M.; Mayr, N.; Stierstorfer, J.; Weyrauther, M. Maximum compaction of ionic organic explosives:bis(hydroxylammonium)5,5'-dinitromethyl-3,3'-bis(1,2,4-oxa-diazolate) and its derivatives. Chem. Eur. J. 2014, 20, 1410-1417.

14. Song, J.; Zhou, Z.; Cao, D.; Huang, H.; Liang, L.; Wang, K. and Zhang, J. Z. 2-(Dinitromethylene)-1-nitro-1,3-diazacyclopentane-based energetic salts. Anorg. Allg. Chem. 2012, 638, 811-820.

15. Li, H.; Zhao, F.-Q.; Gao, H.-X.; Tong, J.-F.; Wang, B.-Z.; Zhai, L.-J.; Huo, H. Three energetic salts based on oxy-bridged bis(gem-dinitro) furazan: syntheses, structures and thermal behaviors. Inorg. Chim. Acta 2014, 423, 256-262.

16. Wang, B.-Z.; Zhai, L.-J.; Lian, P.; Li Y.-N.; Li, H.; Huo, H.; Li, X.-Z. Novel synthesis of 3,3-bis(fluorodinitromethyl)difurazanyl ether (FOF-13). Chin. J. Energ. Mater. 2014, 22, 884-886.

17. Sheldrick, G.M. SAINT (version 6.02), SADABS (version 2.03), Madison (WI, USA): Bruker AXS Inc.; 2002.

18. Sheldrick, G.M. SHELXL-97, a Program for Crystal Structure Solution, University of Göttingen: Göttingen (Germany); 1997.

19. Zhang, X.-Z.; Li, L.-X.; Li, H.-H.; You Z.-L. and Zhu, H.-L. Synthesis, characterization and crystal structures of oxovanadium(V) complexes derived from similar aroylhydrazone ligands. Bull. Chem. Soc. Ethiop. 2015, 29, 423-430.

20. Sheng, G.-H.; You Z.-L. and Zhu, H.-L. Synthesis and characterization and crystal structures of a dixoomolybdenum(VI) complex derived from $N^{\prime}$-(2-hydroxy-4-diethylaminobenzylidene)-4-hydroxybenzohydrazide. Bull. Chem. Soc. Ethiop. 2014, 28, 315-319.

21. Li, H.; Zhao, F.-Q.; Wang, B.-Z.; Zhai, L.-J.; Lai W.-P. and Liu, N. A new family of energetic salts based on oxybridged bis(dinitromethyl)furazan: syntheses, characterization and properties. $R S C A d v$. 2015, 5, 21422-21429.

22. Liang, L.-X.; Cao, D.; Song, J.-H.; Huang, H.; Wang, K.; Bian, C.; Dong, X. and Zhou, Z. Synthesis and characteristics of novel energetic salts based on bis( $N$-dinitroethyl)aminofurazan. J. Mater. Chem. A 2013, 1, 8857-8865.

23. Song, J.; Zhou, Z.; Dong, X.; Huang, H.; Cao, D.; Liang, L.; Wang, K.; Zhang, J.; Chen, F.$\mathrm{X}$. and $\mathrm{Wu}, \mathrm{Y}$. Super-high-energy materials based on bis(2,2-dinitroethyl)nitramine. $J$. Mater. Chem. 2012, 22, 3201-3209.

24. Gao, H.; Joo, Y.-H.; Parrish, D.A.; Vo, T.; Shreeve, J.M. 1-Amino-1-hydrazino- 2,2dinitroethene and corresponding salts: synthesis, characterization, and thermolysis studies. Chem. Eur. J. 2011, 17, 4613-4618.

25. Allen, F.H.; Kennard, O.; Watson, D.G.; Brammer, L.; Orpen, A.G.; Taylor, R. Tables of bond lengths determined by X-ray and neutron diffraction. part 1. Bond lengths in organic compounds. J. Chem. Soc., Perkin Trans. 1987, 2, S1-S19. 